\title{
Kemampuan Komunikasi Matematika Siswa Berdasarkan Gaya Berpikir Acak Abstrak Dan Sekuensial Abstrak
}

\author{
Nurhami ${ }^{1}$, Suaedi $^{2}$, Ma'rufi $^{2}$ \\ SMA Negeri 9 Luwu $^{1}$ \\ Universitas Cokroaminoto Palopo ${ }^{2,3}$ \\ Email: nurhami94@gmail.com¹,Suaedif@gmail.com², marufi@uncp.ac.id ${ }^{3}$
}

\begin{abstract}
Abstrak. Penelitian ini bertujuan unntuk menggambarkan kemampuan komunikasi matematika siswa berdasarkan gaya berpikir yang dimiliki. Penelitian ini merupakan penelitian kualitatif deskriptif yang dilakukan di SMAN 9 Luwu. Subjek penelitian yaitu 1 siswa yang memiiki gaya berpikir acak abstrak dan 1 siswa yang memiliki gaya berpikir sekuensial abstrak. Instrumen dalam penelitian in yaitu peneliti sebagai instrumen utama, serta ter gaya berpikir, tes kemampuan komunikasi dan pedoman wawancara sebagai instrumen pendukung. Teknik triangulasi yang digunakan adalah triangulasi metode. Data yang diperoleh dianalisis mengacu pada teknik analisis data model Miles dan Huberman. Hasil penelitian ini yaitu: 1) subjek acak abstrak dalam memahami wacana mampu menyampaikan informasi yang diketahui dan ditanyakan pada masalah secara lisan, namun tidak menuliskan informasi yang ditanyakan, dan tidak mampu menyampaikan kesimpulan hasil penyelesaian. Kemampuan tata bahasa, subjek menggunakan simbol dan istilah matematika yang kurang sesuai. Kemampuan strategis, subjek mampu menyampaikan metode penyelesaian dengan menuliskan langkah-langkah penyelesaian secara runtut tapi tidak selesai. Sehingga tidak memenuhi indikator kemampuan komunikasi matematika, dan 2) subjek sekuensial abstrak dalam memahami wacana mampu menyampaikan informasi yang diketahui dan ditanyakan pada masalah secara lisan dan tertulis dan mampu menyampaikan kesimpulan hasil penyelesaian secara lisan dan tertulis. Kemampuan tata bahasa, subjek menggunakan simbol dan istilah matematika yang sesuai. Kemampuan strategis, subjek mampu menyampaikan metode penyelesaian dengan menuliskan langkah-langkah penyelesaian secara runtut dan benar. Sehingga memenuhi semua indikator kemampuan komunikasi matematika
\end{abstract}

\section{Kata Kunci: Komunikasi, gaya berpikir, matematika}

\begin{abstract}
Abstrak.This study aims to describe students' mathematical communication skills based on their thinking style. This research is a descriptive qualitative research conducted at SMAN 9 Luwu. The research subject is 1 student who has abstract random thinking style and 1 student who has abstract sequential thinking style. The instruments in this study are the researcher as the main instrument, as well as thinking styles, communication skills tests and interview guidelines as supporting instruments. The triangulation technique used is method triangulation. The data obtained were analyzed referring to the data analysis technique of the Miles and Huberman model. The results of this study are: 1) abstract random subjects in understanding discourse are able to convey information that is known and asked about the problem orally, but does not write down the information asked, and is not able to convey the conclusions of the completion results. Grammatical ability, the subject uses symbols and mathematical terms that are not appropriate. Strategic ability, the subject is able to convey the method of completion by writing down the steps of completion in a coherent manner but not finished. So that it does not meet the indicators of mathematical communication skills, and 2) abstract sequential subjects in understanding discourse are able to convey information that is known and asked about the problem orally and in writing and is able to convey the conclusions of the completion results orally and in writing. Grammatical ability, subject to use appropriate mathematical symbols and terms. Strategic ability, the subject is able to convey the method of completion by writing down the steps of completion in a coherent and correct manner. So that it fulfills all indicators of mathematical communication skills.
\end{abstract}

Keywords: Communication, thinking style, mathematics

\section{A. Pendahuluan}

Kemampuan komunikasi matematika merupakan salah satu tujuan dari belajar matematika. Tanpa kemampuan komunikasi matematika, maka siswa tidak mampu menyampaikan ide dan gagasan matematisnya kepada orang lain terkhusus kepada teman dan 
gurunya. Hal ini sejalan dengan pendapat Rosliawati (Permata, Kartono, \& Sunarmi, 2015) yang mengatakan bahwa tanpa kemampuan komunikasi matematis seseorang tidak mampu menyammpaikan pernyataan sesuai dengan keinginanya.

Menurut Bernard (Rahmawati, Bernard, \& Akbar, 2018), kemampuan komunikasi sangat penting untuk siswa miliki supaya siswa dapat memahami permasalahan matematika yang diberikan dan siswa mampu mengunkapkan ide serta gagasan dalam menyelesaikan persoalan matematika serta menciptakan siswa untuk berpikir kritis, logis, kreatif dan mandiri. Selain itu, kemampuan komunikasi matematika mempunyai peranan penting dalam pembelajaran matematika (Permata et.al, 2015) karena (1) alat untuk mengeksplotasi ide matematika dan membantu kemampuan siswa dalam melihat berbagai keterkaitan materi matematika, (2) alat untuk mengukur pertumbuhan pemahaman dan merefleksikan pemahaman matematika pada siswa, (3) alat untuk mengorganisasikan pemikiran matematika siswa, dan (4) alat untuk mengkonstruksikan pengetahuan matematika, pengembangan pemecahan masalah, peningkatan penalaran, menumbuhkan rasa percaya diri, serta peningkatan keterampilan sosial.

Salah satu pelajaran yang membutuhkan kemampuan komunikasi matematika dalam menyelesaikan suatu permasalahan adalah materi sistem persamaan linear tiga variabel. Sistem persamaan linear tiga variabel adalah materi matematika yang sangat membantu manusia dalam kehidupan sehari-hari.

Siswa memiliki cara yang berbeda-beda mengkomunikasikan gagasan yang dimilikinya, hal tersebut dikarenakan setiap individu memiliki cara mengelola dan mentransformasi informasi berbeda-beda. Berdasarkan hal tersebut, patut menjadi perhatian dalam proses pembelajaran adalah bagaimana cara siswa berpikir secara lebih efektif, karena pada dasarnya siswa memiliki cara berpikir yang berbeda-beda. Perbedaan tersebut merupakan suatu cara yang dimiliki oleh masing-masing siswa, cara-cara tersebut yang biasa dikenal dengan gaya berpikir.

Santrock (2004) mengemukakan gaya belajar dan gaya berpikir merupakan suatu cara yang dipilih seseorang dalam menggunakan kemampuannya. Gaya berpikir menurut Yunus (Muflihah, Ratnaningsih, \& Apiati, 2019) adalah suatu pola pikir yang membedakan cara seseorang menerima dan mengola informasi, serta kemudian menggunakan informasi itu untuk mengatur kehidupan dengan cara tertentu. Sedangkan Sudjana (2005) mengatakan ada beberapa perbedaan gaya berpikir yaitu "Setiap orang memiliki gaya berpikir masing-masing yang dapat diidentifikasi, dimanfaatkan dan dikembangkan keunggulannya, serta diperkuat sehingga setiap orang menjadi peserta didik yang lebih berhasil dalam belajarnya".

Gregorc (Deporter \& Hernacki, 2015) mengelompokkan gaya berpikir menjadi 4 bagian yaitu sekuensial konkret, sekuensial abstrak, acak kongkret dan acak abstrak. Seseorang yang memiliki pemikiran sekuensial konkret berpegang pada kenyataan dan proses informasi dengan cara yang teratur, linear dan sekuensial. Sedangkan seorang yang memiliki pemikiran acak kongkret mempunyai sikap eksperimental yang diiringi dengan perilaku yang kurang terstruktur. Lain halnya dengan seseorang yang memiliki pemikiran acak abstrak dimana dunia nyatanya adalah dunia perasaan dan emosi. Mereka tertarik pada nuansa dan sebagian lagi cenderung pada mistimisme. Sedangkan seseorang yang memiliki pemikiran sekuensial abstark adalah mereka yang suka berpikir dalam konsep dan menganalisis informasi. Dalam penelitian ini kelompok gaya berpikir yang akan dikaji adalah gaya berpikir acak abstrak dan sekuensial abstrak

Berdasarkan studi pendahuluan pada hari Senin tanggal 9 Desember 2019 yang dilakukan peneliti pada 68 siswa kelas X MIA yang telah mempelajari materi sistem persamaan linear tiga variabel terlihat bahwa aspek-aspek indikator kemampuan komunikasi matematika yang muncul dari jawaban siswa pada tes awal yang diberikan berupa kemampuan memahami wacana (discourse competence). Namun demikan, jawaban siswa tersebut masih terlihat kurang jelas dan tidak lengkap langkah penyelesaian tes awal yang diberikan penulis. Sedangkan aspek 
indikator yang belum terlihat adalah kemampuan tata bahasa (grammatical competence) dan kemampuan strategis (strategic competence).

Untuk mengungkap indikator yang belum terlihat, maka peneliti tertarik untuk melakukan penelitian dengan judul Kemampuan Komunikasi Matematika Siswa dalam Menyelesaikan Masalah sistem persamaan linear tiga variabel berdasarkan Gaya Berpikir Acak Abstrak dan Sekuensial Abstrak.

\section{B. Metodologi Penelitian}

Penelitian ini adalah penelitian deskriptif dengan menggunakan pendekatan kualitatif atau dinamakan penelitian deskriptif kualitatif. Moleong (2012) penelitian kualitatif adalah penelitian yang bermaksud untuk memahami fenomena tentang apa yang dialami oleh subjek penelitian misalnya perilaku, persepsi, motivasi, tindakan secara holistic dan dengan cara deskripsi dalam bentuk kata-kata dan bahasa pada suatu konteks khusus yang alamiah dan dengan memanfaatkan berbagai metode alamiah. Penelitian ini menggunakan pendekatan kualitatif dengan harapan agar dapat mengungkapkan secara cermat kemampuan komunikasi matematika siswa dalam menyelesaikan masalah sistem persamaan linear tiga variabel berdasarkan gaya berpikir acak abstrak dan sekuensial abstrak.

Penelitian ini dilaksanakan di SMA Negeri 9 Luwu, subjek penelitian ini adalah siswa kelas $\mathrm{X}$ yang tediri 1 siswa yang memiliki gaya berpikir acak abstrak dan 1 siswa yang memiliki gaya berpikir sekuensial abstrak. Instrumen penelitian ini ada dua yaitu instrumen utama dan instrumen pendukung. Instrumen utama adalah peneliti sendiri sedangkan instrumen pendukung yaitu tes gaya berpikir, tes kemampuan komunikasi dan pedoman wawancara. Data yang dieroleh terlebih dahulu dilakukan triangulasi untuk memperoleh data yang valid dan reliable. Teknik triangulasi yang digunakan yaitu triangulasi metode. Teknik analisis data yang digunakan dalam penelitian ini mengaju pada teknik analisis data model Miles dan Huberman.

\section{Prosedur Penelitian}

Prosedur penelitian ini sebagai berikut: tahap persiapan, tahap pelaksanaan, dan tahap analisis.

a. Tahap persiapan

Prosedur yang dilaksanakan sebagai berikut:

a) Menyiapkan draf instrumen berupa tes gaya berpikir, soal tes kemampuan komunikasi matematika dan pedoman wawancara yang nantinya akan digunakan sebagai alat mengumpulkan data.

b) Mengadakan validasi instrumen yang mengacu pada lembar validasi.

c) Berdasarkan masukan dan saran dari validator, peneliti memperbaiki draf instrumen. Instrumen yang telah valid ini selanjutnya digunakan untuk mengumpulkan data.

b. Tahap pelaksanaan

Pada tahap ini dilakukan, sebagai berikut:

a) Peneliti memilih subjek penelitian. Proses pemilihan subjek dilakukan dengan cara peneliti menetapkan kriteria pemilihan subjek yang dilakukan melalui tes gaya berpikir.

b) Subjek yang memenuhi kriteria pemilihan akan diberikan soal komunikasi matematika kemudian dianalisis kemampuan komunikasi matematika subjek, dan melakukan wawancara. Selanjutnya dilakukan metode triangulasi yaitu dengan membandingkan data subjek secara tertulis dari hasil tes dan data dari hasil wawancara. Data hasil triangulasi yang sama merupakan data subjek yang valid. Sedangkan data yang berbeda direduksi atau dijadikan temuan lain dalam penelitian ini. 
c) Setelah diperoleh data yang valid, data tersebut kemudian digunakan untuk mengetahui kemampuan komunikasi matematika siswa.

c. Tahap analisis

Tahap analisis dilakukan dengan teknik analisis data yang ditentukan dalam rancangan penelitian. Tahapan kegiatan analisis, adalah sebagai berikut:

a) Membuat transkip hasil wawancara.

b) Menyajikan data hasil tes dan transkip wawancara.

c) Mendeskripsikan kemampuan komunikasi subjek penelitian.

d) Menarik kesimpulan mengenai kemampuan komunikasi siswa dalam menyelesaikan masalah SPLTV.

\section{Hasil Penelitian dan Pembahasan}

\section{Hasil Penelitian}

\section{Kemampun Komunikasi Matematika Siswa yang memiliki gaya berpikir acak abstrak (AA)}

Berdasarkan hasil tes dan wawancara pada soal nomor 1 dan nomor 2, kemampuan komunikasi subjek AA dalam menyelesaikan masalah persamaan linear tiga variabel dapat dilihat pada tabel berikut.

Tabel 1. Kemampuan komunikasi matematika subjek AA dalam menyelesaikan masalah persamaan linear tiga variabel

\begin{tabular}{|c|c|}
\hline $\begin{array}{l}\text { Indikator } \\
\text { Komunikasi } \\
\text { Matematika }\end{array}$ & Uraian \\
\hline $\begin{array}{l}\text { Kemampuan } \\
\text { memahami }\end{array}$ & $\begin{array}{l}\text { 1) Subjek mampu menyampaikan informasi yang diketahui dengan lengkap baik } \\
\text { secara lisan maupun tertulis. }\end{array}$ \\
\hline wacana & $\begin{array}{l}\text { 2) Subjek mampu menyampaikan secara lisan informasi yang ditanyakan pada soal, } \\
\text { namun tidak menuliskan informasi yang ditanyakan pada lembar jawaban. } \\
\text { 3) Subjek tidak mampu menyampaikan kesimpulan hasil akhir penyelesaian } \\
\text { masalah baik secara lisan maupun tertulis }\end{array}$ \\
\hline $\begin{array}{l}\text { Kemampuan } \\
\text { tata bahasa }\end{array}$ & $\begin{array}{l}\text { 1) Subjek mampu mengubah kalimat verbal pada soal menjadi kalimat matematika. } \\
\text { 2) Subjek mampu menggunakan simbol-simbol matematika dalam menyelesaikan } \\
\text { masalah, namun subjek hanya mampu menyampaikan secara tertulis. } \\
\text { 3) Subjek mampu menggunakan istilah matematika, namun belum bisa } \\
\text { mendefinisikan secara jelas sehingga menimbulkan ketidakjelasan arti }\end{array}$ \\
\hline $\begin{array}{l}\text { Kemampuan } \\
\text { strategis }\end{array}$ & $\begin{array}{l}\text { 1) Subjek mampu menyampaikan strategi menyelesaikan masalah secara lisan } \\
\text { 2) Subjek mampu menghubungkan antara variabel-variabel yang digunakan dalam } \\
\text { langkah-langkah menyelesaikan soal. } \\
\text { 3) Subjek mampu menyampaikan relasi matematika dengan aljabar } \\
\text { 4) Subjek tidak mampu menyelesaikan masalah secara runtut }\end{array}$ \\
\hline
\end{tabular}

Sumber: Data primer setelah di olah (2021)

Berdasarkan tabel di atas, dapat disimpulkan bahwa subjek dengan gaya berpikir Acak Abstrak memiliki kemampuan komunikasi matematika sebagai berikut.

a. Indikator memahami wacana, subjek mampu menyampaikan informasi yang diketahui dengan lengkap baik secara lisan maupun tertulis, mampu menyampaikan secara lisan informasi yang ditanyakan pada soal, namun tidak menuliskan informasi yang ditanyakan pada lembar jawaban, seta tidak mampu menyampaikan kesimpulan hasil akhir penyelesaian masalah baik secara lisan maupun tertulis. 
b. Indikator kemampuan tata bahasa, subjek mampu mengubah kalimat verbal pada soal menjadi kalimat matematika, mampu menggunakan simbol-simbol matematika dalam menyelesaikan masalah, namun subjek hanya mampu menyampaikan secara tertulis, mampu menggunakan istilah matematika, namun belum bisa mendefinisikan secara jelas sehingga menimbulkan ketidakjelasan arti.

c. Indikator kemampuan strategis, subjek mampu menyampaikan strategi menyelesaikan masalah secara lisan, mampu menghubungkan antara variabel-variabel yang digunakan dalam langkah-langkah menyelesaikan soal, mampu menyampaikan relasi matematika dengan aljabar namun tidak mampu menyelesaikan masalah secara runtut.

\section{Kemampun Komunikasi Matematika Siswa yang memiliki gaya berpikir Sekuensial Abstrak (SA)}

Berdasarkan hasil tes dan wawancara pada soal nomor 1 dan nomor 2, kemampuan komunikasi subjek SA dalam menyelesaikan masalah persamaan linear tiga variabel dapat dilihat pada tabel berikut.

Tabel 2. Kemampuan komunikasi matematika subjek SA dalam menyelesaikan masalah persamaan linear tiga variabel

Indikator

Komunikasi

Uraian

Matematika

Kemampuan memahami

wacana

1) Subjek mampu menyampaikan informasi yang diketahui dengan lengkap baik secara lisan maupun tertulis

2) Subjek mampu menyampaikan informasi yang ditanyakan pada soal baik secara lisan maupun tertulis

3) Subjek mampu menyampaikan kesimpulan hasil akhir penyelesaian masalah baik secara lisan maupun tertulis

Kemampuan tata 1) Subjek mampu mengubah kalimat verbal pada soal menjadi kalimat bahasa matematika

2) Subjek mampu menggunakan simbol-simbol matematika dalam menyelesaikan masalah

3) Subjek mampu menggunakan istilah matematika

Kemampuan $\quad$ 1) Subjek mampu menyampaikan strategi menyelesaikan masalah secara lisan

strategis $\quad$ 2) Subjek mampu menghubungkan antara variabel-variabel yang digunakan dalam langkah-langkah menyelesaikan soal.

3) Subjek mampu menyampaikan relasi matematika dengan aljabar

4) Subjek mampu menyelesaikan masalah secara runtut dan benar

Sumber: Data primer setelah di olah (2021)

Berdasarkan tabel di atas, dapat disimpulkan bahwa subjek dengan gaya berpikir Sekuensial Abstrak memiliki kemampuan komunikasi matematika sebagai berikut:

a. Indikator memahami wacana, subjek mampu menyampaikan informasi yang diketahui dengan lengkap baik secara lisan maupun tertulis, mampu menyampaikan informasi yang ditanyakan pada soal baik secara lisan maupun tertulis, serta mampu menyampaikan kesimpulan hasil akhir penyelesaian masalah baik secara lisan maupun tertulis.

b. Indikator kemampuan tata bahasa, subjek mampu mengubah kalimat verbal pada soal menjadi kalimat matematika, mampu menggunakan simbol-simbol matematika dalam menyelesaikan masalah, namun subjek hanya mampu menyampaikan secara tertulis, mampu menggunakan istilah matematika.

c. Indikator kemampuan strategis, subjek mampu menyampaikan strategi menyelesaikan masalah secara lisan, mampu menghubungkan antara variabel-variabel yang digunakan 
dalam langkah-langkah menyelesaikan soal, mampu menyampaikan relasi matematika dengan aljabar dan mampu menyelesaikan masalah secara runtut dan benar.

\section{Pembahasan}

Berdasarkan hasil penelitian berikut di jabarkan pembahasan kemampuan komunikasi matematika siswa yang memiliki gaya berpikir acak abstrak dan siswa siswa yang memiliki gaya berpikir sekuensial abstrak dalam menyelesaikan masalah persamaan linear tiga variabel.

Kemampuan komunikasi siswa yang memiliki gaya berpikir acak abstrak (AA) dalam menyelesaikan masalah persamaan linear tiga variabel yaitu Pada indikator kemampuan memahami wacana, subjek AA mampu memahami informasi-informasi yang ada diberikan pada soal baik yang diketahui maupun yang ditanyakan. Namun, subjek tidak mampu menyampaikan kesimpulan hasil akhir penyelesaian masalah yang diperoleh. Hal ini sejalan dengan temuan Lestanti, Isnarto dan Supriono (2016) siswa dengan gaya berpikir acak abstrak di tanya apa yang dia pahami dari permasalahan yang diberikan, siswa mampu mengungkapkan informasi-informasi yang ada sesuai dengan masalah yang diberikan. Pada indikator kemampuan tata bahasa subjek AA mampu mengubah kalimat verbar menjadi kalimat matematika, mampu menggunakan simbol-simbol matematika dalam menyelesaikan masalah, mampu menggunakan istilah metematika, namun belum mampu mendefenisikan secara jelas istilah tersebut sehingga menimbulkan ketidakjelasan arti. Pada indikator kemampuan strategis, subjek AA mampu menyampaikan strategi pemecahan masalah yang digunakan, mampu menghubungkan antara variabel-variabel yang digunakan dalam langkah-langkah penyelesaian yang dilakukan, mampu menyampaikan relasi matematika dengan aljabar, namu subjek tidak mampu menyelesaikan masalah secara runtut. Sejalan dengan penelitian Kurniawati, (2017) saat mengerjakan masalah yang diberikan, subjek AA kurang lengkap dalam menuliskan langkah pengerjaannya dan jawabannya kurang tepat. Meskipun begitu, subjek AA memahami cara mengerjakan masalah yang diberikan.

Kemampuan komunikasi siswa yang memiliki gaya berpikir sekuensial abstrak (SA) dalam menyelesaikan masalah persamaan linear tiga variabel yaitu Pada indikator kemampuan memahami wacana, subjek SA mampu memahami informasi-informasi yang ada diberikan pada soal baik yang diketahui maupun yang ditanyakan, dan subjek mampu menyampaikan kesimpulan hasil akhir penyelesaian masalah yang diperoleh. Hal ini sejalan dengan temuan Zakir (2015) bahwa siswa dengan gaya berpikir SA cenderung menuliskan fakta yang diketahui secara lengkap dan terurut dengan cara identifikasi masalah yang dilakukan. Lebih lanjut temuan Fauzi, Ratnaningsih, Rustina, \& Nimah (2020) siswa yang memiliki gaya berpikir sequensial abstrak mampu memilih kesimpulan akhir yang tepat sesuai yang diminta dalam soal. Pada indikator kemampuan tata bahasa subjek SA mampu mengubah kalimat verbar menjadi kalimat matematika, mampu menggunakan simbol-simbol matematika dalam menyelesaikan masalah, mampu menggunakan istilah metematika. Pada indikator kemampuan strategis, subjek SA mampu menyampaikan strategi pemecahan masalah yang digunakan, mampu menghubungkan antara variabel-variabel yang digunakan dalam langkah-langkah penyelesaian yang dilakukan, mampu menyampaikan relasi matematika dengan aljabar, dan subjek mampu menyelesaikan masalah secara runtut dan benar. Sejalan dengan temuan penelitian Kurniawati (2017) siswa dengan gaya berpikir sequensial abstrak mampu menuliskan langkah pengerjaan secara runtut dan lengkap dan melakukan semua perhitungan yang diperlukan. 


\section{Kesimpulan}

Berdasarkan hasil analisis dan pembahasan, di peroleh kesimpulan yaitu 1) Kemampuan komunikasi matematika siswa dengan gaya berpikir Acak Abstrak dalam menyelesaikan masalah SPLTV adalah, kemampuan memahami wacana mampu menyampaikan informasi yang diketahui dan ditanyakan pada masalah secara lisan, namun tidak menuliskan informasi yang ditanyakan, dan tidak mampu menyampaikan kesimpulan hasil penyelesaian. Kemampuan tata bahasa, subjek menggunakan simbol dan istilah matematika yang kurang sesuai. Kemampuan strategis, subjek mampu menyampaikan metode penyelesaian dengan menuliskan langkah-langkah penyelesaian secara runtut tapi tidak selesai. Sehingga tidak memenuhi indikator kemampuan komunikasi matematika, 2) Kemampuan komunikasi matematika siswa dengan gaya berpikir Acak Abstrak dalam menyelesaikan masalah SPLTV adalah memahami wacana mampu menyampaikan informasi yang diketahui dan ditanyakan pada masalah secara lisan dan tertulis dan mampu menyampaikan kesimpulan hasil penyelesaian secara lisan dan tertulis. Kemampuan tata bahasa, subjek menggunakan simbol dan istilah matematika yang sesuai. Kemampuan strategis, subjek mampu menyampaikan metode penyelesaian dengan menuliskan langkah-langkah penyelesaian secara runtut dan benar. Sehingga memenuhi semua indikator kemampuan komunikasi matematika.

\section{DAFTAR PUSTAKA}

Deporter, B., \& Hernacki, M. (2015). Quantum Learning Membiasakan Belajar Nyaman dan Menyenangkan. Bandung: Kaifa.

Fauzi, F. A., Ratnaningsih, N., Rustina, R., \& Nimah, K. (2020). Analisis kemampuan berpikir kritis matematis peserta didik ditinjau dari gaya berpikir gregorc. Journal of Authentic Research on Mathematics Education (JARME), 2(2), 96-107.

Kurniawati, W. (2017). Analisis Kemampuan Pemecahan Masalah Menurut Polya Dalam Pembelajaran Problem Based Learning Berdasarkan Gaya Berpikir Gregorc Siswa Kelas Vii Smp Negeri 1 Gondang Tahun Ajaran 2016/2017 (Doctoral dissertation, Universitas Muhammadiyah Surakarta).

Lestanti,M.M., Isnarto \& Supriono (2016). Analisis Kemampuan Pemecahan Masalah Ditinjau Dari Karakteristik Cara Berpikir Siswa Dalam Model Problem Based Learning. Unnes Journal of Mathematics Education, 5(1), 16-23.

Moleong, L, J. (2012). Metodologi Penelitian Kualitatif. Bandung: PT Remaja. Rosdakarya

Muflihah, I. S., Ratnaningsih, N., \& Apiati, V. (2019). Analisis kemampuan koneksi matematis ditinjau dari gaya berpikir peserta didik. Journal of Authentic Research on Mathematics Education (JARME), l(1).

Permata, Kartono, \& Sunarmi. (2015). Analisis Kemampuan Komunikasi Matematis Siswa Kelas Viii Smp Pada Model Pembelajaran Tsts Dengan Pendekatan Scientific. Unnes Journal of Mathematics Education., 4(2), 127- 133.

Rahmawati, N. S., Bernard, M., \& Akbar, P. (2018). Analisis Kemampuan Komunikasi Matematik Siswa Smk Pada Materi Sistem Persamaan Linier Dua Variabel (Spldv. Journal On Education, 1(2), 344-352.

Santrock, J. W. (2004). Psikologi Pendidikan (Edisi Kedua). Jakarta: Kencana.

Sudjana, D. (2005). Strategi Pembelajaran. Bandung: Falah Production. 
Zakir, M. (2015). Description Of Logical Reasoning In Solving Mathematics Problemss Based On Students'thinking Style Of Students At SMPN 2 Pinrang. Daya Matematis: Jurnal Inovasi Pendidikan Matematika, 3(2), 152-165. 